\title{
Distribution and Rate of Movement of the Curtovirus Beet mild curly top virus (Family Geminiviridae) in the Beet Leafhopper
}

\author{
Maria J. Soto and Robert L. Gilbertson
}

Department of Plant Pathology, University of California, 1 Shields Ave., Davis 95616.

Current address of M. J. Soto: Donald Danforth Plant Science Center, 975 North Warson Road, St. Louis, MO 63132.

Accepted for publication 13 November 2002.

\begin{abstract}
Soto, M. J., and Gilbertson, R. L. 2003. Distribution and rate of movement of the curtovirus Beet mild curly top virus (family Geminiviridae) in the beet leafhopper. Phytopathology 93:478-484.

A polymerase chain reaction (PCR)-based method for the detection of the curtovirus Beet mild curly top virus (BMCTV, previously named the Worland strain of Beet curly top virus) was developed and used to investigate the BMCTV-beet leafhopper interaction. Using PCR and a BMCTV-specific primer pair, an $\approx 1.1$-kb BMCTV DNA fragment was

$48 \mathrm{~h}$ on BMCTV-infected shepherd's purse plants. BMCTV was detected in the digestive tract after all AAPs, in the hemolymph after AAPs of $3 \mathrm{~h}$ or greater, and in the salivary glands after AAPs of $4 \mathrm{~h}$ or greater. The amount of virus detected in the hemolymph and salivary glands increased with AAP length. The virus persisted for up to 30 days in leafhoppers (given a 3-day AAP on BMCTV-infected plants) maintained on corn plants, a nonhost for BMCTV, but transovarial transmission was not detected. These results are consistent with a persistent but nonpropagative mode of circulative transmission.
\end{abstract} amplified from adult leafhoppers and from the organs involved in circulative transmission: the digestive tract, hemolymph, and salivary glands. The temporal distribution of BMCTV in the leafhopper was determined using insects given acquisition access periods (AAPs) ranging from 1 to
Additional keywords: Circulifer tenellus, curly top disease, geminivirus, insect vector, leafhopper transmission, persistent transmission.
Plant viruses in the family Geminiviridae have circular, singlestranded DNA genomes encapsidated in twinned icosahedral particles. Geminiviruses are divided into four genera (Mastrevirus, Curtovirus, Topocuvirus, and Begomovirus) based on viral genome structure, host range, and type of insect vector $(30,31$, 35,42,46). Viruses in the genera Mastrevirus and Curtovirus have a monopartite genome and are transmitted by leafhoppers. Mastreviruses infect monocotyledonous plants and are transmitted by a number of leafhopper species in the genus Cicadulina, whereas curtoviruses infect dicotyledonous plants and are transmitted by the beet leafhopper, Circulifer tenellus. The genus Topocuvirus includes only Tomato pseudo-curly top virus, which has a monopartite genome, is transmitted by treehoppers, and infects dicotyledonous plants. Most members of the genus Begomovirus have a bipartite genome, with some exceptions such as the monopartite Tomato yellow leaf curl virus (TYLCV). Begomoviruses are transmitted by whiteflies (e.g., Bemisia tabaci and B. argentifolii) and infect dicotyledonous plants.

Beet curly top virus (BCTV), the type member of the Genus Curtovirus, causes curly top disease in more than 300 plant species from 44 different families (1). Symptoms of curly top disease (CTD) include stunted growth, leaf yellowing, upward and inward curling of leaves, vein swelling and distortion, and phloem necrosis (1). In the Western United States (e.g., California, Washington, and Utah), CTD can be an economically important disease of crops such as sugarbeet, tomato, pepper, bean, cucurbits (e.g., squash, melon, muskmelon, and cucumber), and spinach. Studies of BCTV isolates associated with CTD in the Western

Corresponding author: R. L. Gilbertson; E-mail address: rlgilbertson@ucdavis.edu

Publication no. P-2003-0218-02R

(C) 2003 The American Phytopathological Society
United States have revealed three distinct strains of BCTV: California/Logan, $\mathrm{CFH}$, and Worland, which differ in DNA sequence and symptoms induced in certain hosts (39-41). In recognition of the sequence divergence among these BCTV strains (they share $\approx 80 \%$ sequence identity) and their differential pathogenicity in sugarbeet plants, these strains have been elevated to species status and renamed (39-41,46). The California/Logan strain retained the name Beet curly top virus (BCTV), the $\mathrm{CFH}$ strain was named Beet severe curly top virus (BSCTV), and the Worland strain was named Beet mild curly top virus (BMCTV) (40). Thus, there are now three curtovirus species that may cause CTD.

These three curtoviruses are transmitted from plant to plant via the beet leafhopper (C. tenellus). In the Western United States, virus transmission by the leafhopper occurs during the course of an extensive annual migration (1). In California, adults overwinter on perennial weeds in the foothills of the coastal range and, in the late winter or early spring, lay eggs on annual weeds that have germinated as a result of the winter rains. Nymphs are thought to acquire the virus from infected annual and perennial plants and, as these hosts dry out in mid- to late spring, viruliferous adult leafhoppers migrate to cultivated areas where they feed on crop plants or weeds concentrated along roadsides and irrigation ditches. Leafhoppers migrate from weeds to agricultural crops, where they undergo several generations and spread BCTV, BSCTV, and BMCTV. In the late fall, adult beet leafhoppers migrate back to overwintering areas.

Previous studies of the curtovirus-leafhopper interaction were done with a variety of isolates, all of which were referred to as BCTV (1). Thus, although these studies were likely performed with some combination of BCTV (i.e., the California/Logan strain of BCTV), BMCTV, and BSCTV, there are no known differences in leafhopper transmission among these curtoviruses. These studies revealed that the curtovirus-leafhopper relationship is 
characterized by a short latent period, extended retention of the virus by the vector, and transtadial transmission (1), which is consistent with a persistent circulative mode of insect transmission. Studies of other geminivirus-insect interactions also have suggested a persistent circulative mode of transmission $(15,27)$. However, recent studies of the TYLCV-B. tabaci interaction have raised the possibility that some geminiviruses have evolved a more extensive interaction with their insect host, perhaps even a propagative mode of transmission $(10,12,23,34)$.

The polymerase chain reaction (PCR) has become a useful tool for the detection of geminiviruses in their vectors $(6,22,29,36)$ and to study the virus-vector interaction $(11,20,33)$. For example, the mastrevirus, Maize streak virus (MSV), was detected in the gut, hemolymph, and the head of viruliferous leafhopper vectors, whereas it was restricted to the gut of the nonvector leafhoppers, thereby identifying a barrier to viral transmission in the insect (20). MSV persisted in the leafhopper vector for up to 28 days, but there was no evidence of viral replication in the insect vector (20). A similar PCR-based approach has been used to follow the movement of the begomoviruses Squash leaf curl virus (SLCV) and TYLCV in whiteflies $(11,33)$. Results of these studies were consistent with a persistent circulative mode of transmission $(11,20,33)$.

In this report, the development of a PCR-based method for the detection of BMCTV (previously named the Worland strain of BCTV) in the beet leafhopper is described. This method was used to (i) detect BMCTV in the different organs involved in virus circulation and (ii) determine the temporal distribution and persistence of the virus in the leafhopper.

\section{MATERIALS AND METHODS}

Leafhoppers, plants, and virus isolate. Beet leafhoppers were reared on sugarbeet plants kept in a controlled environment chamber maintained at $30^{\circ} \mathrm{C}$ day and $25^{\circ} \mathrm{C}$ night with a 16 -h photoperiod. Adult insects were used in all experiments. The isolate of BMCTV used in this study, BMCTV-W4, was derived from an infectious clone in pBMCTV-W4 (monomer) and pBMCTV-W1.2 (multimer) (38). BMCTV-W4 came from pepper plants with curly top symptoms from New Mexico.

Shepherd's purse plants (Capsella bursa-pastoris [L.] Medik) initially were infected with BMCTV-W4 by feeding leafhoppers with extracts of protoplasts transfected with pBMCTV-W1.2 (38). Leafhoppers were fed on protoplast extracts overnight through a parafilm membrane, and five to seven insects were placed into small clip-on leaf cages $(2.5 \mathrm{~cm}$ in diameter by $2 \mathrm{~cm}$ high $)$ that were clipped onto leaves of healthy shepherd's purse plants for an inoculation access period (IAP) of 3 to 5 days. These BMCTVinfected shepherd's purse plants were used as source plants to obtain viruliferous leafhoppers, which were used to obtain additional BMCTV-infected shepherd's purse and sugarbeet plants.

Extraction of DNA from plants and leafhoppers. Nucleic acids were extracted from leaf tissues as previously described (32). Two methods for preparing a PCR template from beet leafhoppers were evaluated. In the first method (method 1), a crude extract was prepared by grinding individual leafhoppers in $100 \mu \mathrm{l}$ of STE buffer (100 mM NaCl, $10 \mathrm{mM}$ Tris-HCl [pH 8.0], and $1 \mathrm{mM}$ EDTA) in an Eppendorf tube with a pestle (Kontes, Vineland, NJ). The resulting suspension was clarified by centrifugation $(14,000 \times g$ for $5 \mathrm{~min})$ and 1,5 , or $10 \mu \mathrm{l}$ was used in the PCR. In the second method (method 2), individual leafhoppers were ground in 100 to $300 \mu \mathrm{l}$ of STE, the suspension was clarified by centrifugation, and the supernatant was extracted with an equal volume of phenol/chloroform. Nucleic acids were recovered by ethanol precipitation, suspended in $20 \mu \mathrm{l}$ of water, and $1 \mu \mathrm{l}$ was used in the PCR.

PCR detection of BMCTV. The primer pair BMCTVv377 (5'CTAGCAGTATCGACCAGTTG-3') and BMCTVc1509 (5'-GA-
CATTGACTGGAGACCGTT-3') was designed from the sequence of BMCTV-W4. These primers direct the amplification of an $\approx 1.1$-kb BMCTV fragment, which includes the entire capsid protein open reading frame (ORF) and parts of the $\mathrm{V} 2, \mathrm{~V} 3, \mathrm{C} 2$, and C3 ORFs. The PCR parameters used to amplify the BMCTV DNA fragment from plant and leafhopper extracts were as follows: an initial denaturing step at $94^{\circ} \mathrm{C}$ for $5 \mathrm{~min}$ followed by $94^{\circ} \mathrm{C}$ for $1 \mathrm{~min}$ (denaturing), $60^{\circ} \mathrm{C}$ for $2 \mathrm{~min}$ (annealing), and $72^{\circ} \mathrm{C}$ for 2 min (extension) for 25 cycles, with a final extension step of $72^{\circ} \mathrm{C}$ for $10 \mathrm{~min}$. PCR-amplified DNA fragments were analyzed by electrophoresis in $0.8 \%$ agarose gels in $1 \times$ TAE buffer (40 mM Tris-acetate and $1 \mathrm{mM}$ EDTA), stained with ethidium bromide (EtBr) and visualized with UV light.

Southern blot hybridization analysis. DNA fragments were fractionated in $0.8 \%$ TAE-agarose gels and transferred to Hybond $\mathrm{N}+$ nylon membranes (Amersham, Arlington Heights, IL) as previously described (17). Blots were hybridized under highstringency conditions with pBMCTV-W4 DNA labeled with $\left[\alpha^{32} \mathrm{P}\right]$-dCTP by nick-translation (Nick Translation System, BRL, Gaithersburg, MD).

Collection of hemolymph and dissection of the digestive tract and salivary glands from adult leafhoppers. Adult leafhoppers were collected by aspiration and immobilized by exposure to acetone vapors for 3 to $5 \mathrm{~min}$. Individual leafhoppers were placed, ventral side up, on double-sided tape attached to a glass slide. The left middle leg was detached from the mesothorax with a sterile hypodermic needle (27 gauge), and hemolymph collected with a sterile glass capillary pipette and transferred to a 1.5-ml Eppendorf tube containing $300 \mu \mathrm{l}$ of STE buffer. The insect then was placed in a drop of water (on another slide), and dissected using a dissecting microscope. Heads (with salivary glands) were carefully teased away from the thorax with a pair of forceps. In some cases, the entire head was used in the PCR; whereas, in other cases, the salivary glands were dissected. The rest of the body was used in the PCR, or the digestive tracts were dissected. Dissected salivary glands and digestive tracts were rinsed three times with sterile distilled water. Heads, bodies, salivary glands, and digestive tracts were placed individually into an Eppendorf tube with $300 \mu \mathrm{l}$ of STE buffer, and extracts prepared using method 1 or method 2 as described previously.

Rate of movement of BMCTV through the leafhopper. Leafhoppers were collected from colonies raised on uninfected sugarbeet plants and starved for about $2 \mathrm{~h}$. Next, they were caged with BMCTV-infected shepherd's purse plants. Four insects each were collected after acquisition access periods (AAPs) of 1, 2, 3, $4,5,8,24$, and $48 \mathrm{~h}$. Hemolymph was collected, salivary glands and digestive tracts were dissected, and these tissues were tested for BMCTV by PCR. This experiment was repeated five times.

Persistence of BMCTV in the leafhopper and transovarial transmission. Two hundred nonviruliferous leafhoppers were allowed a 3-day AAP on BMCTV-infected sugarbeet plants. They then were transferred to sweet corn plants (Jubilee hybrid) and four insects were collected at 6-day intervals for a month and tested for BMCTV by PCR. During these experiments, the progeny of these leafhoppers were reared on these sweet corn plants, and nymphs were collected and tested by PCR for transovarial transmission of BMCTV. At the completion of these experiments, leaves of each sweet corn plant were tested for BMCTV by PCR. This experiment was repeated five times.

\section{RESULTS}

PCR detection of BMCTV in the beet leafhopper. The development of a PCR-based method for detecting BMCTV in leafhoppers required a BMCTV-specific primer pair and a reliable protocol for preparation of the PCR (BMCTV DNA) template. The primer pair, BMCTVv377 and BMCTVc1509, consistently directed the amplification of an $\approx 1.1-\mathrm{kb}$ BMCTV fragment from 
cloned BMCTV DNA and extracts of BMCTV-infected plants, whereas no DNA fragments were amplified from equivalent extracts of uninfected plants (data not shown). In all cases tested, the identity of this 1.1-kb BMCTV DNA fragment was confirmed by hybridization with the BMCTV DNA probe. This primer pair, hereafter referred to as the BMCTV primer pair, was used throughout the study.

Two methods for generating a DNA template from leafhoppers were evaluated. In the first method, crude extracts were prepared from individual leafhoppers given a 5-day AAP on BMCTV-infected shepherd's purse plants and from nonviruliferous leafhoppers by grinding in $100 \mu \mathrm{l}$ of STE buffer. After a brief centrifugation, 1, 5, and $10 \mu \mathrm{l}$ of this crude extract were used in the PCR with the BMCTV primer pair. Over the course of six independent experiments, the BMCTV DNA fragment was amplified from extracts of only 5 of 46 leafhoppers given a 5-day AAP on BMCTV-infected plants, irrespective of whether male or female insects were tested (Fig. 1A). Furthermore, when amplification of the BMCTV DNA fragment occurred, it was usually with smaller volumes of extract ( 1 or $5 \mu \mathrm{l}$ versus $10 \mu \mathrm{l}$ ) (Fig. 1A). To determine whether the failure to amplify the BMCTV DNA fragment was due to PCR inhibitors, an additional PCR was conducted in which $50 \mathrm{ng}$ of pBMCTV-W4 DNA was added into extracts of leafhoppers (given access to BMCTV-infected plants) from which the BMCTV DNA fragment was not amplified. In these cases, the BMCTV DNA fragment was not amplified, whereas it was amplified from control reactions having pBMCTV-W4 DNA only (data not shown). These results indicate that the failure to amplify the BMCTV DNA fragment from the crude leafhopper extracts

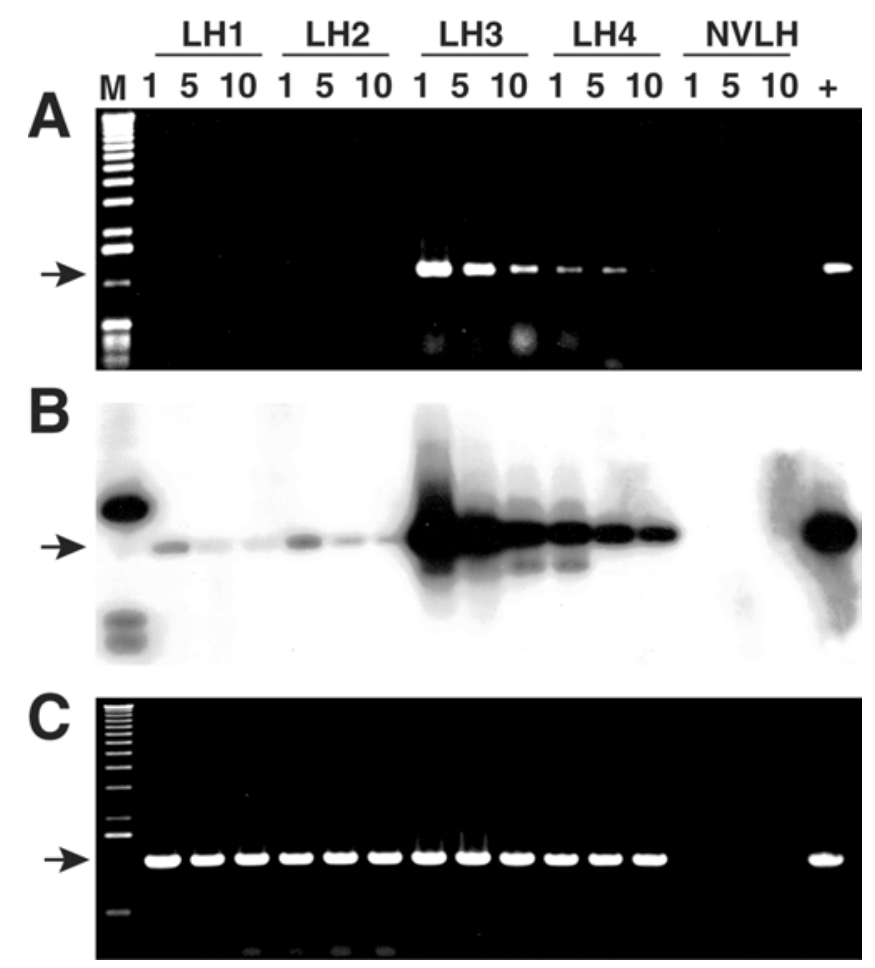

Fig. 1. Detection of Beet mild curly top virus (BMCTV) in beet leafhoppers by polymerase chain reaction (PCR) with a BMCTV-specific primer pair. A, Agarose gel showing PCR products amplified from different amounts of crude extract $(1,5$, or $10 \mu \mathrm{l})$ prepared from four individual leafhoppers (LH1, LH2, LH3, and LH4). B, Southern blot hybridization analysis of the agarose gel in A with a BMCTV-specific DNA probe (pBMCTV-W4). C, Agarose gel showing PCR products amplified from the same leafhopper extracts used for the PCR in A, but with an additional nucleic acid extraction step. No DNA fragment was amplified from a nonviruliferous leafhopper (NVLH), whereas the BMCTV DNA fragment was amplified from a BMCTV-infected shepherd's purse plant (positive [+] control). Arrows indicate the 1.1-kb BMCTV DNA fragment. was due to PCR inhibitors. Southern blot hybridization analysis with the BMCTV probe confirmed the identity of the $1.1-\mathrm{kb}$ BMCTV DNA fragments amplified from acquisition-positive leafhoppers and, in some cases, revealed the amplification of a fragment that was not visible in the EtBr-stained gel (compare Fig. 1A and B). No DNA fragments were detected in Southern blot hybridization analyses of PCR products from nonviruliferous leafhoppers.

Because of the PCR inhibitors, a second method was evaluated in which the crude extract was purified by extraction with phenol/ chloroform and nucleic acids recovered by ethanol precipitation. Using nucleic acid extracts from leafhoppers given a 5-day AAP on BMCTV-infected plants, the BMCTV DNA fragment was amplified from all 36 leafhoppers tested, including male and female insects (Fig. 1C). No DNA fragments were amplified from nucleic acid extracts prepared from nonviruliferous leafhoppers (Fig. 1C). Using this method, BMCTV was detected from individual insects, from groups of 4 to 15 leafhoppers (in a single tube), and from leafhoppers having fed on extracts of protoplasts transfected with infectious BMCTV-W1.2 DNA (data not shown). These results indicate that (i) this PCR method can be used to reliably detect BMCTV in leafhoppers and (ii) leafhoppers given a 5-day AAP on BMCTV-infected plants have acquired sufficient virus for PCR detection and can be considered acquisition-positive.

Distribution of BMCTV in viruliferous leafhoppers. BMCTV is considered to be transmitted by leafhoppers in a circulative manner (i.e., after uptake in the digestive tract, the virus moves through the body of the vector to the salivary glands where it is released during feeding) (1). To determine the distribution of BMCTV in the beet leafhopper, the two extraction methods (methods 1 and 2) were evaluated for PCR detection of BMCTV in the different organs involved in circulative transmission. Extracts were prepared from heads (with salivary glands) and bodies (with the digestive tract) as well as from the digestive tract, hemolymph, and salivary glands. Initial PCR experiments established that (i) the BMCTV fragment was not reliably amplified from intact organs and (ii) the BMCTV DNA fragment was consistently amplified from crude extracts (method 1) of bodies and digestive tracts, but not from those of heads and salivary glands (data not shown). Using method 2 (nucleic acid extracts) and leafhoppers given a 5-day AAP on BMCTV-infected plants, the BMCTV DNA fragment was amplified from heads and bodies of all 16 insects tested (three experiments). In a similar set of experiments, the BMCTV fragment was amplified from digestive tracts, hemolymph, and salivary glands of all 16 insects tested (three

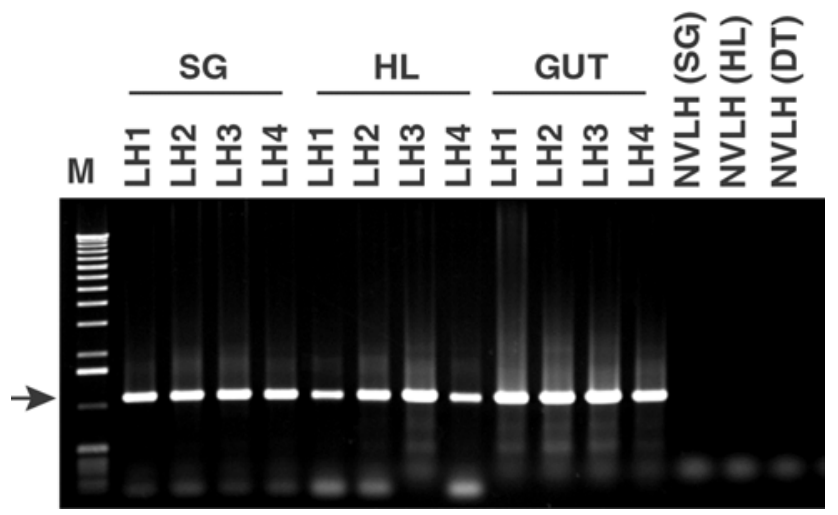

Fig. 2. Detection of Beet mild curly top virus (BMCTV) in the different organs of the beet leafhopper involved in circulative transmission by polymerase chain reaction (PCR) with a BMCTV-specific primer pair. Agarose gel showing PCR products amplified from DNA extracts prepared from salivary glands (SG), hemolymph (HL), and digestive tract (GUT/DT) of four acquisition-positive leafhoppers (LH1, LH2, LH3, and LH4). No DNA fragment was amplified from these tissues collected from a nonviruliferous leafhopper (NVLH). Arrow indicates the 1.1-kb BMCTV DNA fragment. 
experiments) (Fig. 2). These results suggest that (i) the distribution of BMCTV in the leafhopper is consistent with circulative transmission, (ii) preparation of nucleic acid extracts (method 2) is needed for consistent amplification of the BMCTV DNA fragment from leafhopper tissues, and (iii) PCR inhibitors are located in the salivary glands.

Rate of movement of BMCTV through the leafhoppers. To assess the temporal distribution of BMCTV in leafhoppers, insects were collected from BMCTV-infected shepherd's purse plants after AAPs of $1,2,3,4,5,8,24$, or $48 \mathrm{~h}$. A total of 20 individual insects were analyzed for each time point over the course of five independent experiments. BMCTV was detected in the digestive tracts of all insects regardless of AAP (Fig. 3A; Table 1), whereas no DNA fragments were amplified from digestive tracts of nonviruliferous leafhoppers. These results establish that leafhoppers were feeding on the BMCTV-infected plants within $1 \mathrm{~h}$ and that ingestion of the virus occurs relatively rapidly. To assess if leafhoppers could transmit BMCTV after a 1-h AAP (i.e., did they acquire sufficient virions to become viruliferous), leafhoppers were given a 1-h AAP on BMCTV-infected shepherd's purse plants, and then two insects each were transferred to a healthy shepherd's purse plant for a 5-day IAP. Of 12 inoculated plants (three experiments), 8 developed typical BMCTV symptoms approximately 12 days postinoculation, and BMCTV was detected in leaves of these plants by PCR with the BMCTV primer pair (data not shown). Plants inoculated with nonviruliferous leaf-
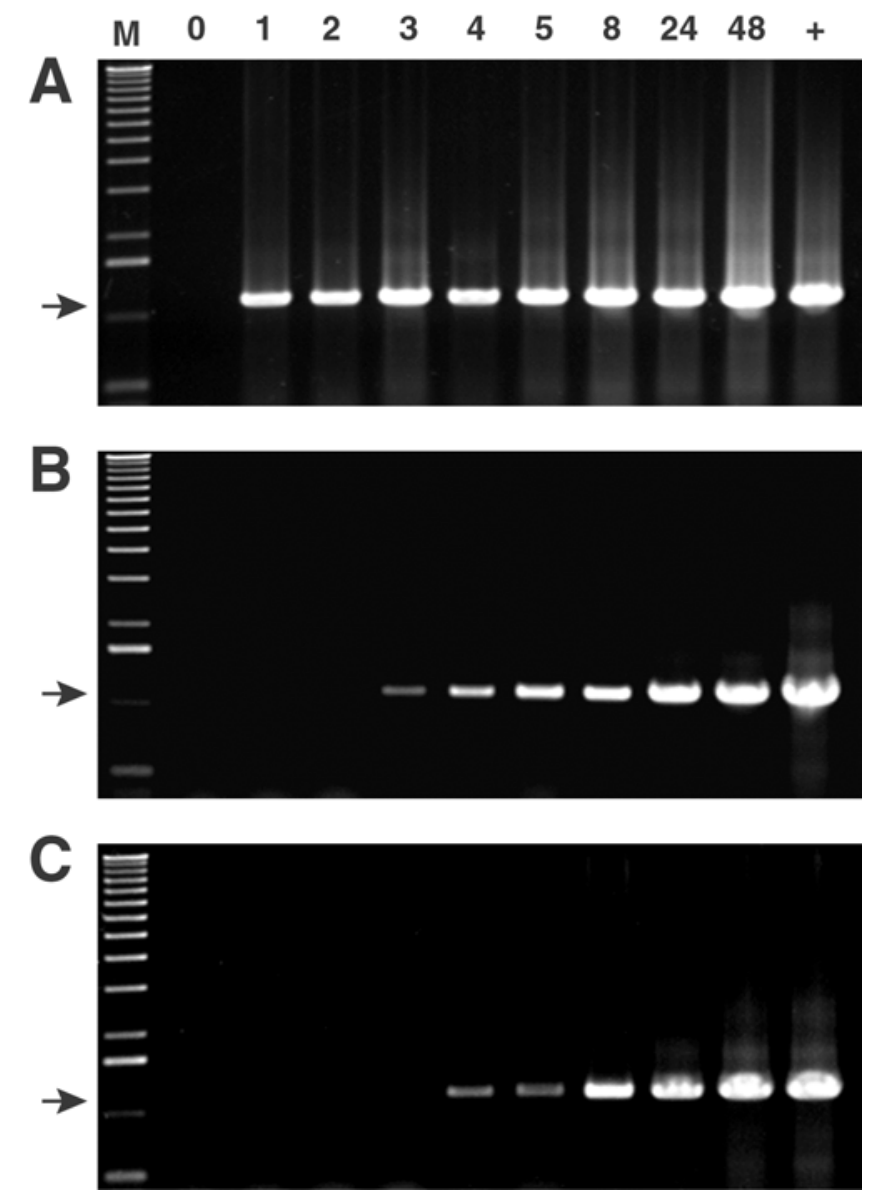

Fig. 3. Temporal distribution of Beet mild curly top virus (BMCTV) in the beet leafhopper. Agarose gels showing polymerase chain reaction products amplified from DNA extracts prepared from the $\mathbf{A}$, digestive tract, $\mathbf{B}$, hemolymph, and $\mathbf{C}$, salivary glands of leafhoppers given acquisition access periods (AAPs) on BMCTV-infected shepherd's purse plants ranging from 0 to $48 \mathrm{~h}$. The BMCTV DNA fragment was amplified from a BMCTV-infected shepherd's purse plant (positive [+] control). Arrows indicate the 1.1-kb BMCTV DNA fragment. hoppers did not develop any symptoms, nor was the BMCTV DNA fragment detected in leaves of these plants. These results indicate that the amount of virus acquired during a 1-h AAP was sufficient for a high proportion of insects to become viruliferous.

BMCTV DNA was first detected in the hemolymph of some insects $(60 \%)$ after the 3-h AAP, and then consistently from hemolymph of insects having longer AAPs (Fig. 3B; Table 1). Detection in salivary glands of some insects (45\%) occurred after the 4-h AAP, and then consistently from salivary glands of insects having longer AAPs (Fig 3C; Table 1). The amount of virus detected in the hemolymph and salivary glands increased with the length of the AAP, based on the intensity of the BMCTV DNA fragment in EtBr-stained gels (Fig. 3B and C).

There was some variability in PCR detection of BMCTV in individual leafhoppers given identical AAPs. For example, BMCTV detection in the digestive tract, hemolymph, and salivary glands of four individual insects given a 5-h AAP is presented in Figure 4. Here, BMCTV was detected in the digestive tract, hemolymph, and salivary glands of three leafhoppers, but only in the digestive tract of the other leafhopper (LH2, Fig. 4).

Persistence of BMCTV in the leafhopper and transovarial transmission. To assess the capacity of BMCTV to persist in the leafhopper vector, leafhoppers were given a 3-day AAP on BMCTV-infected sugarbeet plants and then maintained on sweet corn plants, a nonhost for BMCTV (1). Four insects each were collected at 6-day intervals over a 30-day period and individually

TABLE 1. Temporal distribution of Beet mild curly top virus (BMCTV) in the digestive tract, hemolymph, and salivary glands of the beet leafhopper based upon amplification of a BMCTV DNA fragment by polymerase chain reaction $(\mathrm{PCR})$ with a $\mathrm{BMCTV}$-specific primer pair ${ }^{\mathrm{a}}$

\begin{tabular}{lccc}
\hline AAP $^{\mathrm{b}}$ & Digestive tract & Hemolymph & Salivary glands \\
\hline 0 & $0 / 20$ & $0 / 20$ & $0 / 20$ \\
1 & $20 / 20$ & $0 / 20$ & $0 / 20$ \\
2 & $20 / 20$ & $0 / 20$ & $0 / 20$ \\
3 & $20 / 20$ & $12 / 20$ & $0 / 20$ \\
4 & $20 / 20$ & $18 / 20$ & $9 / 20$ \\
5 & $20 / 20$ & $18 / 20$ & $18 / 20$ \\
8 & $20 / 20$ & $20 / 20$ & $19 / 20$ \\
24 & $20 / 20$ & $19 / 20$ & $19 / 20$ \\
48 & $20 / 20$ & $20 / 20$ & $20 / 20$ \\
\hline
\end{tabular}

a Number of insects that tested positive for BMCTV by PCR (i.e., in which the 1.1-kb BMCTV DNA fragment was amplified) per total number of insects tested. Numbers represent totals of five independent experiments.

b AAP, acquisition access period in hours.

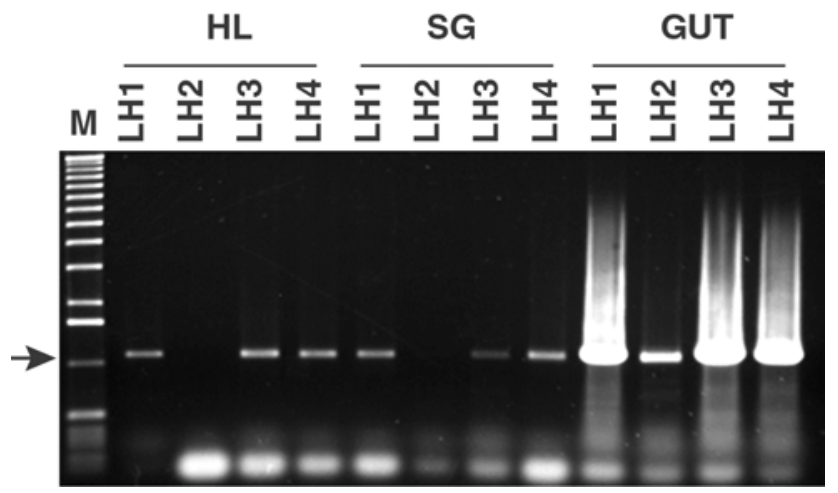

Fig. 4. Detection of Beet mild curly top virus (BMCTV) in leafhoppers following a 5-h acquisition access period (AAP) on BMCTV-infected shepherd's purse plants. Agarose gel showing polymerase chain reaction (PCR) products amplified from DNA extracts prepared from hemolymph (HL), salivary glands (SG), and digestive tracts (GUT) by PCR with a BMCTV-specific primer pair. Four individual leafhoppers (LH1, LH2, LH3, and LH4) were analyzed. Arrow indicates the 1.1-kb BMCTV DNA fragment. 
tested for BMCTV by PCR. In two independent experiments, all leafhoppers tested immediately after the 3-day AAP had ingested BMCTV, although the amount of virus acquired varied among insects, based upon differences in the intensity of the BMCTV DNA fragment in EtBr-stained gels (data not shown). However, after leafhoppers given access to BMCTV-infected plants had been kept on corn plants for 30 days, BMCTV was no longer detected in some of the insects (two of eight); whereas, for others, the amount of BMCTV DNA detected was either highly reduced (three of eight) or comparable (three of eight) to that detected from insects tested immediately after the 3-day AAP (data not shown). These results suggested that the amount of BMCTV in leafhoppers had decreased over the 30-day period on corn plants. To minimize variability among individual leafhoppers, three additional independent experiments were conducted in which the four leafhoppers collected at each time point were pooled and analyzed for BMCTV by PCR. In all three experiments, the BMCTV DNA fragment was amplified from insects collected at each time point. The amount of BMCTV detected in leafhoppers, based on the intensity of the amplified BMCTV fragment in the EtBr-stained gels, remained the same or decreased slightly over the course of these experiments (data not shown). The results of these experiments established that BMCTV persists in the leafhopper for as long as 1 month. Furthermore, although these PCR experiments were not quantitative, the fact that increased amounts of BMCTV DNA were not detected from leafhoppers maintained on corn plants suggests that the virus did not replicate in the insect vector.

To test for transovarial transmission of BMCTV, the progeny (nymphs) of the leafhoppers given a 3-day AAP on BMCTV-infected plants and maintained on corn plants were collected and tested for BMCTV by PCR. The BMCTV DNA fragment was not amplified from nucleic acid extracts of any of the 70 nymphs tested (five experiments), whereas it was amplified from equivalent extracts prepared from leafhoppers given a 5-day AAP on BMCTV-infected plants. These results suggest that BMCTV was not transovarially transmitted.

At the end of these experiments, DNA was extracted from newly emerged leaves of each of the five corn plants used in each of the five experiments, and used in the PCR with the BMCTVspecific primer pair. BMCTV DNA was not detected from any of the corn leaves, consistent with corn not being a host of BMCTV.

\section{DISCUSSION}

PCR detection of BMCTV in the beet leafhopper. A reliable PCR method for detection of BMCTV in beet leafhoppers and leafhopper tissues was developed and used to study the distribution, rate of movement, and persistence of the virus in the insect vector. This method was based upon the amplification of an $\approx 1.1$-kb BMCTV DNA fragment with a BMCTV-specific primer pair (BMCTVv377 and BMCTVc1509) from nucleic acid extracts prepared from whole leafhoppers or leafhopper organs. The nucleic acid extraction procedure was required because of PCR inhibitors associated with leafhopper heads or salivary glands. A similar PCR detection method for MSV in leafhoppers also included a DNA purification step (20). In contrast, crude extracts were successfully used for PCR detection of the begomoviruses TYLCV, Tomato mottle virus (ToMoV), and SLCV in whiteflies $(22,33,36)$. Also, whereas consistent PCR detection of TYLCV was obtained from intact digestive tracts and salivary glands of whiteflies (11), inconsistent detection of BMCTV was obtained from intact leafhopper digestive tracts and salivary glands. Thus, PCR detection of geminiviruses from whiteflies is simpler compared with leafhoppers, which have a considerably larger body size and associated inhibitors of the PCR.

This BMCTV PCR detection method can be used for basic studies of the BMCTV-leafhopper interaction and as a tool in epidemiological studies. For example, this method could be used to monitor for viruliferous leafhoppers in overwintering areas in order to predict potential epidemics or to identify areas for chemical control of leafhoppers. PCR detection of TYLCV in whiteflies has been successfully used to demonstrate the effectiveness of a host-free period in the Dominican Republic in reducing TYLCV incidence (36).

BMCTV-beet leafhopper interaction. In persistent circulative transmission, virus is ingested from the phloem of infected plants during insect feeding. Virions pass through the food canal to the digestive tract where they are absorbed, presumably via receptormediated endocytosis (27). Virions gain access to the hemolymph and are transported to the salivary glands where they are taken up and passed, in saliva, to plants during feeding. Thus, the detection of BMCTV in each of the organs involved in circulative transmission (digestive tract, hemolymph, and salivary glands) is fully consistent with the circulative transmission of BCTV (1). The exact location of BMCTV in the digestive tract (e.g., filter chamber, anterior midgut, mid-midgut, posterior midgut, or hindgut) was not identified.

Viral DNA was detected in the digestive tract after an AAP of 1 $\mathrm{h}$ (shortest AAP tested). Moreover, the amount of virus ingested during this time was sufficient to result in a high proportion of leafhoppers becoming viruliferous. These findings are consistent with previous reports showing high rates of BCTV transmission (44 to 64\%) by leafhoppers given a 1-h AAP on BCTV-infected plants, and the capacity of leafhoppers to ingest BCTV in AAPs as short as 1 to $2 \mathrm{~min}(2,37)$. Thus, the beet leafhopper is very efficient at acquiring BCTV virions, presumably due to a capacity to rapidly access the phloem and to ingest large quantities of phloem sap in short periods of time. In contrast, whitefly acquisition and transmission rates for begomoviruses tend to be considerably lower. For example, after 5- to 6-day AAPs on ToMoVinfected tomato plants, whitefly acquisition and transmission rates were 3 and $4 \%$, respectively (18). For SLCV, whitefly transmission frequencies were low $(\approx 3 \%)$ after 1 - or 2-h AAPs, but increased to 30 to $50 \%$ following longer AAPs (24 to $72 \mathrm{~h}$ ).

BMCTV passed across the leafhopper digestive tract in less than $3 \mathrm{~h}$, based upon detection in the hemolymph of insects given a 3-h AAP. MSV also was detected in the hemolymph of C. mbila after AAPs of $3 \mathrm{~h}$ or greater (20). The begomoviruses TYLCV and SLCV were detected in the hemolymph of $B$. tabaci after AAPs of 1.5 and $2 \mathrm{~h}$ or greater, respectively $(10,33)$. These results show that geminiviruses representing the three main genera can rapidly cross the digestive tract barrier, consistent with an active mechanism, such as receptor-mediated uptake of virions. The existence of such a mechanism is further supported by the fact that the digestive tract acts as a barrier to geminivirus transmission by nonvector leafhoppers (20) and whiteflies (33). In the luteovirusaphid system, uptake of the virions occurs via receptor-mediated endocytosis in midgut or hindgut cells $(9,13,14)$. A similar mechanism has been proposed for uptake of MSV in the filter chamber of the leafhopper vector (21), and for uptake of ToMoV and $\mathrm{CaLCV}$ in the filter chamber and anterior midgut of the whitefly vector (18).

The detection of BMCTV in the salivary glands after an AAP of only $4 \mathrm{~h}$ reveals that the virus rapidly (within $1 \mathrm{~h}$ ) accumulates in this organ after entering the hemolymph. These findings are consistent with those of Bennett and Wallace (3), who established that the minimum time required for BCTV to circulate inside the insect vector before it became viruliferous (i.e., the latent period) was $4 \mathrm{~h}$. Similarly, the leafhopper-transmitted geminivirus, Chickpea chlorotic dwarf virus (CpCDV), had a latent period of only $2 \mathrm{~h}$ (16). Whereas TYLCV and SLCV were detected in the hemolymph of whiteflies after AAPs of only 1.5 to $2 \mathrm{~h}$, TYLCV was not detected in salivary glands until after a 7-h AAP $(4,5$, $11,23)$ and SLCV had a minimum latent period of 6 to $8 \mathrm{~h}(33)$. Together, these results suggest that there are differences in the rate of movement of geminiviruses in the hemolymph of leafhoppers 
versus whiteflies. As shown for luteoviruses $(7,43,45)$ and TYLCV $(24,25)$, circulation of virions in the insect hemolymph may involve an interaction with endosymbiont-derived chaperonins (i.e., a GroEL homolog). In both systems (aphids and whiteflies), it was proposed that the GroEL homolog protects the virus from degradation in the hemolymph $(7,24,25,43-45)$. It will be interesting to determine the role, if any, of chaperonins in the movement of BMCTV in the leafhopper.

BMCTV persisted in the beet leafhopper for as long as 1 month. However, BMCTV did not appear to replicate in the insect, based on the fact that the amount of viral DNA detected in leafhoppers provided a 3-day AAP on BMCTV-infected plants and then maintained on nonhost corn plants did not increase over time. This is consistent with previous studies showing that (i) the beet leafhopper can carry the virus for several weeks, (ii) persistence of the virus was correlated with the length of AAP, and (iii) the capacity of the insect to transmit the virus declined over time, regardless of AAP $(2,8)$. However, the PCR detection method for BMCTV is not quantitative; therefore, BMCTV replication in the vector cannot be absolutely ruled out. MSV also persisted in the leafhopper vector for up to 30 days and, using real-time PCR, it was established that the titer of MSV decreased in C. mbila over time (20). Therefore, MSV does not appear to replicate in the leafhopper. To explain the long retention of curtoviruses in the beet leafhopper in the absence of replication, it was suggested that leafhoppers accumulate large amounts of virus, which is released gradually during feeding (2). It will be important to identify where in the insect this occurs. The leafhopper gut was proposed as the likely storage organ for MSV; whereas, in the aphid-luteovirus system, it was considered to be the hemolymph $(20,43,45)$.

Several lines of evidence suggest that the mode of BMCTV transmission by the beet leafhopper is persistent and circulative, but nonpropagative. First, BMCTV was detected in the organs involved in circulative transmission and in a temporal distribution consistent with this mode of transmission. Second, movement of the virus to the salivary glands, as well as insect transmission (2), occurred after a relatively short latent period $(4 \mathrm{~h})$; propagative viruses have long (days) latent periods $(27,28)$. Third, BMCTV was retained in the leafhopper for a long period (30 days); however, in contrast to propagative viruses, no increase in viral titer in the insect vector was detected after removal from the viral source. Finally, BMCTV was not transovarially transmitted, which is a property of many propagative viruses.

The situation is less clear for whitefly-transmitted begomoviruses. These viruses persist in the insect for days to weeks; for example, TYLCV persists for 10 to 20 days (26) and Chino del tomate virus (CdTV) for up to 9 days in the whitefly vector (19). Whereas most studies have suggested that begomoviruses do not replicate in their whitefly vectors (15), results with the TYLCVwhitefly system have suggested a more complex interaction. First, Mehta et al. (23), using DNA hybridization methods, detected an increase in TYLCV DNA in whiteflies maintained on nonhost cucumber plants; this suggested that TYLCV might replicate in the whitefly. However, similar experiments conducted with Tomato yellow leaf curl Sardinia virus failed to reveal an increase in viral DNA in B. tabaci (3). Second, TYLCV was transmitted transovarially in whiteflies for at least two generations (12), and it also was transmitted between insects during copulation (10). Finally, acquisition of TYLCV by whiteflies has been shown to reduce life expectancy and fecundity $(10,34)$. Together, these results suggest that TYLCV may have a more intricate interaction with whiteflies (e.g., possibly replicating in the vector or establishing an association with the whitefly reproductive system or endosymbionts) (12).

Our PCR-based study of the curtovirus-leafhopper interaction adds to previous studies of mastrevirus-leafhopper and begomovirus-whitefly interactions $(11,20,33)$. Together, these studies are consistent with a persistent circulative mode of insect transmis- sion, and reveal a number of differences between whitefly and leafhopper transmission of geminiviruses.

\section{ACKNOWLEDGMENTS}

This research was supported in part by a Faculty Research Grant from the University of California-Davis College of Agriculture and Environmental Sciences to R. L. Gilbertson and a fellowship from BIDCONICIT (Venezuela) to M. J. Soto. We thank B. Falk for providing a colony of the beet leafhopper.

\section{LITERATURE CITED}

1. Bennett, C. W. 1971. The curly top disease of sugarbeet and other plants, Monogr. No. 7. The American Phytopathological Society, St. Paul, MN.

2. Bennett, C. W., and Wallace, H. E. 1938. Relation of the curly top virus to the vector, Eutettix tenellus. J. Agric. Res. 56:31-52.

3. Caciagli, P., and Bosco, D. 1997. Quantitation over time of tomato yellow leaf curl geminivirus DNA in its whitefly vector. Phytopathology 87:610-613.

4. Caciagli, P., Bosco, D., and Al-Bitar, L. 1995. Relationships of the Sardinian isolate of tomato yellow leaf curl geminivirus with its whitefly vector Bemisia tabaci Gen. Eur. J. Plant Pathol. 101:163-170.

5. Cohen, S., and Nitzany, F. E. 1966. Transmission and host range of the tomato yellow leaf curl virus. Phytopathology 56:1127-1131.

6. Deng, D., McGrath, P. F., Robinson, D. J., and Harrison, B. D. 1994. Detection and differentiation of whitefly-transmitted geminiviruses in plants and vector insects by the polymerase chain reaction with degenerate primers. Ann. Appl. Biol. 125:327-336.

7. Filichkin, S. A., Brumfield, S., Filichkin, T. P., and Young, M. J. 1997. In vitro interactions of the aphid endosymbiotic symL chaperonin with barley yellow dwarf virus. J. Virol. 71:569-577.

8. Freitag, J. H. 1936. Negative evidence on multiplication of curly-top virus in the beet leafhopper, Eutettix tenellus. Hilgardia 10:305-342.

9. Garret, A., Kerlan, C., and Thomas, D. 1993. The intestine is a site of passage for potato leafroll virus from the gut lumen into the haemocoel in the aphid vector, Myzus persicae Sulz. Arch. Virol. 131:377-392.

10. Ghanim, M., and Czosnek, H. 2000. Tomato yellow leaf curl geminivirus (TYLCV-Is) is transmitted among whiteflies (Bemisia tabaci) in a sexrelated manner. J. Virol. 74:4738-4745.

11. Ghanim, M., Morin, S., and Czosnek, H. 2001. Rate of Tomato yellow leaf curl virus translocation in the circulative transmission pathway of its vector, the whitefly Bemisia tabaci. Phytopathology 91:188-196.

12. Ghanim, M., Morin, S., Zeidan, M., and Czosnek, H. 1998. Evidence for transovarial transmission of tomato yellow leaf curl virus by its vector, the whitefly Bemisia tabaci. Virology 240:295-303.

13. Gildow, F. E. 1985. Transcellular transport of barley yellow dwarf virus into the hemocoel of the aphid vector, Rhopalosiphum padi. Phytopathology 75:292-297.

14. Gildow, F. E. 1993. Evidence for receptor-mediated endocytosis regulating luteovirus acquisition by aphids. Phytopathology 83:270-277.

15. Harrison, B. D. 1985. Advances in geminivirus research. Annu. Rev. Phytopathol. 23:55-82.

16. Horn, N. M., Reddy, S. V., and Reddy, D. V. R. 1994. Virus-vector relationships of chickpea chlorotic dwarf geminivirus and the leafhopper Orosius orientalis (Hemiptera: Cicadellidae). Ann. Appl. Biol. 124: 441-450.

17. Hou, Y.-M., and Gilbertson, R. L. 1996. Increased pathogenicity in a pseudorecombinant bipartite geminivirus correlates with intermolecular recombination. J. Virol. 70:5430-5436.

18. Hunter, W. B., Hiebert, E., Webb, S. E., Tsai, J. H., and Polston, J. E. 1998. Location of geminiviruses in the whitefly Bemisia tabaci (Homoptera: Aleyrodidae). Plant Dis. 82:1147-1151.

19. Idris, A. M., Smith, S. E., and Brown, J. K. 2001. Ingestion, transmission, and persistence of Chino del tomate virus (CdTV), a New World begomovirus, by Old and New World biotypes of the whitefly vector Bemisia tabaci. Ann. Appl. Biol. 139:145-154.

20. Lett, J.-M., Granier, M., Hippolyte, I., Grondin, M., Royer, M., Blanc, S., Reynaud, B., and Peterschmitt, M. 2002. Spatial and temporal distribution of geminiviruses in leafhoppers of the genus Cicadulina monitored by conventional and quantitative polymerase chain reaction. Phytopathology 92:65-74.

21. Markham, P. G. 1992. Transmission of maize streak virus by Cicadulina species. XIX Int. Congr. Entomol. 213.

22. Mehta, P., Wyman, J. A., Nakhla, M. K., and Maxwell, D. P. 1994. Polymerase chain reaction detection of viruliferous Bemisia tabaci (Homoptera: Aleyrodidae) with two tomato-infecting geminiviruses. J. Econ. Entomol. 87:1285-1290. 
23. Mehta, P., Wyman, J. A., Nakhla, M. K., and Maxwell, D. P. 1994. Transmission of tomato yellow leaf curl geminivirus by Bemisia tabaci (Homoptera: Aleyrodidae). J. Econ. Entomol. 87:1291-1297.

24. Morin, S., Ghanim, M., Sobol, I., and Czosnek, H. 2000. The GroEL protein of the whitefly Bemisia tabaci interacts with the coat protein of transmissible and nontransmissible begomoviruses in the yeast twohybrid system. Virology 276:404-416.

25. Morin, S., Ghanim, M., Zeidan, M., Czosnek, H., Verbeek, M., and van den Heuvel, J. F. J. M. 1999. A GroEL homologue from endosymbiotic bacteria of the whitefly Bemisia tabaci is implicated in the circulative transmission of tomato yellow leaf curl virus. Virology 256:75-84.

26. Nakhla, M. K., and Maxwell, D. P. 1998. Epidemiology and management of tomato yellow leaf curl disease. Pages 565-583 in: Plant Virus Disease Control. A. Hadidi, R. K. Khetarpal, and H. Koganezawa, eds. The American Phytopathological Society, St. Paul, MN.

27. Nault, L. R. 1997. Arthropod transmission of plant viruses: A new synthesis. Ann. Entomol. Soc. Am. 90:521-541.

28. Nault, L. R., and Ammar, E. D. 1989. Leafhopper and planthopper transmission of plant viruses. Annu. Rev. Entomol. 34:503-530.

29. Navot, N., Zeidan, M., Pichersky, E., Zamir, D., and Czosnek, H. 1992. Use of the polymerase chain reaction to amplify tomato yellow leaf curl virus DNA from infected plants and viruliferous whiteflies. Phytopathology 82:1199-1202.

30. Padidam, M., Beachy, R. N., and Fauquet, C. M. 1995. Classification and identification of geminiviruses using sequence comparisons. J. Gen. Virol. 76:249-263.

31. Padidam, M., Maxwell, D. P., and Fauquet, C. M. 1997. A proposal for naming geminiviruses. Arch. Virol. 142:2553-2562.

32. Rojas, M. R., Gilbertson, R. L., Russell, D. R., and Maxwell, D. P. 1993. Use of degenerate primers in the polymerase chain reaction to detect whitefly-transmitted geminiviruses. Plant Dis. 77:340-347.

33. Rosell, R. C., Torres-Jerez, I., and Brown, J. K. 1999. Tracing the geminivirus-whitefly transmission pathway by polymerase chain reaction in whitefly extracts, saliva, hemolymph, and honeydew. Phytopathology 89:239-246.

34. Rubinstein, G., and Czosnek, H. 1997. Long-term association of tomato yellow leaf curl virus with its whitefly vector Bemisia tabaci: Effect on the insect transmission capacity, longevity and fecundity. J. Gen. Virol. 78:2683-2689.
35. Rybicki, E. P. 1994. A phylogenetic and evolutionary justification for three genera of Geminiviridae. Arch. Virol. 139:49-77.

36. Salati, R., Nahkla, M. K., Rojas, M. R., Guzman, P., Jacquez, J., Maxwell, D. P., and Gilbertson, R. L. 2002. Tomato yellow leaf curl virus in the Dominican Republic: Characterization of an infectious clone, virus monitoring in whiteflies and identification of reservoir hosts. Phytopathology 92:487-496.

37. Severin, H. H. P. 1931. Modes of curly-top transmission by the beet leafhopper, Eutettix tenellus (Baker). Hilgardia 6:253-276.

38. Soto, M. J., and Gilbertson, R. L. 2000. Investigation of the role of the beet curly top virus capsid protein in viral movement and insect transmission. (Abstr.) Phytopathology 90(suppl.):S74.

39. Stanley, J., Markham, P. G., Callis, R. J., and Pinner, M. S. 1986. The nucleotide sequence of an infectious clone of the geminivirus beet curly top virus. EMBO J. 5:1761-1768.

40. Stenger, D. C. 1998. Replication specificity elements of the Worland strain of beet curly top virus are compatible with those of the CFH strain but not those of the Cal/Logan strain. Phytopathology 88:1174-1178.

41. Stenger, D. C., Carbonaro, D., and Duffus, J. E. 1990. Genomic characterization of phenotypic variants of beet curly top virus. J. Gen. Virol. 71:2211-2215.

42. Timmermans, M. C. P., Das, O. P., and Messing, J. 1994. Geminiviruses and their uses as extrachromosomal replicons. Annu. Rev. Plant Physiol. Plant Mol. Biol. 45:79-112.

43. Van den Heuvel, J. F. J. M., Bruyere, A., Hogenhout, S. A., ZieglerGraff, V., Brault, V., Verbeek, M., Van der Wilk, F., and Richards, K. 1997. The N-terminal region of the luteovirus readthrough domain determines virus binding to Buchnera GroEL and is essential for virus persistence in the aphid. J. Virol. 71:7258-7265.

44. Van den Heuvel, J. F. J. M., Hogenhout, S. A., and Van der Wilk, F. 1999. Recognition and receptors in virus transmission by arthropods. Trends Microbiol. 7:71-75.

45. Van den Heuvel, J. F. J. M., Verbeek, M., and Van der Wilk, F. 1994. Endosymbiotic bacteria associated with circulative transmission of potato leafroll virus by Myzus persicae. J. Gen. Virol. 75:2559-2565.

46. Van Regenmortel, M. H. V., Bishop, D. H. L., Fauquet, C., and International Union of Microbiological Societies. Virology Division. 2000. Virus Taxonomy: Classification and Nomenclature of Viruses: Seventh Report of the International Committee on Taxonomy of Viruses. Academic Press, San Diego, CA. 